\title{
Understanding interactions between cementitious materials and microorganisms: a key to sustainable and safe concrete structures in various contexts
}

\author{
Alexandra Bertron
}

Received: 5 August 2014/Accepted: 12 September 2014/Published online: 14 October 2014

(C) The Author(s) 2014. This article is published with open access at Springerlink.com

\begin{abstract}
Building materials can be exposed to microorganisms (mainly bacteria, fungi and algae) in almost every aqueous medium or damp environment, water being the indispensable condition for life development. The activity of microorganisms can be responsible for mineralogical, chemical and microstructural damage to the material (biodeterioration). Deleterious effects can also concern the aesthetics of a building (proliferation of colored biological stains on façades and roofs) or the quality of indoor air (presence of microorganisms in damp buildings). However, microorganisms can also have positive effects (healing of materials) and their action is explored through the development of bio-based protective systems intended for building materials. In all cases, understanding interactions between building materials and microorganisms is an indispensable step toward the development of more sustainable, better quality, safer structures in many environments. This paper presents two examples where the action of microorganisms has-or is likely to have-strong impact on the durability and safety of concrete structures. The first example concerns the biodeterioration of concrete in agricultural and agro-food environments. The second example is that of the abiotic and biotic reactivity of
\end{abstract}

A. Bertron $(\bowtie)$

Laboratoire Matériaux et Durabilité des Constructions (LMDC), UPS, INSA, Université de Toulouse, 135, avenue de Rangueil, 31077 Toulouse Cedex 04, France e-mail: bertron@insa-toulouse.fr nitrates in repository of intermediate-level long-lived nuclear wastes. The paper presents the approaches used to explore and understand the phenomenology of biogeo-chemical interactions in these complex environments. These studies notably comprise the development of test methods and experimental pilots to enable these explorations to be carried out. Current shortcomings in the scientific literature and in the standardization environment are also highlighted.

Keywords Microorganisms - Concrete · Biodeterioration - Organic acids $\cdot$ Nuclear waste repository

\section{Introduction}

Infrastructures and buildings are exposed to microorganisms in a variety of contexts. In every situation where building materials can be in contact with water or moisture, an indispensable condition for life to develop, they can be subject to the action of microorganisms. Interactions between life and materials may, in some cases, condition the service properties, the durability and the safety of building materials, products and structures [1-4]. There is growing awareness of these interactions, which are now the subject of more and more research.

\subsection{General aspects about microorganisms}

Microorganisms are microscopic, pioneer organisms in any development of life, and are ubiquitous in air, 
water and soil. They are characterized by their metabolic functions i.e. all the biochemical reactions through which the microbial cells can develop, grow, react and reproduce (proliferate). The creation of microbial biomass, resulting from a succession of redox reactions, necessitates an energy source (from light or from the oxidation of chemical, organic or inorganic compounds, i.e. electron donors) and a carbon source (organic or inorganic, i.e. $\mathrm{CO}_{2}$ ) [5]. The major mode of classification of microorganisms is based on metabolism, which defines the way microorganisms interact with their environment and notably with substrates (for example, building materials). It is also a resultant of the characteristics of the environment: the type of predominant microorganisms in a given medium is determined by the characteristics of the environment, which act as selection factor from an high initial diversity, e.g. in fully aerobic conditions, ammonium-rich environment, nitrifying microorganisms will become significant (case of sludges from wastewater treatment plant with high solid retention time) [6], whereas in sulfur-rich aerobic media, sulfuroxidizing microorganisms (SOM) will grow (case of crown part of sewer pipes $[7,8]$ ). Besides their rapid adaptation to the environment, one characteristic of microorganisms is their ability to act on the environment. At the surface of a substrate, populations can follow one another and, through their metabolism, cause the chemical conditions to progressively evolve toward more favorable ones (for example, decrease of surface $\mathrm{pH}$ of concrete in sewer environments because of the succession of neutrophilic and acidophilic SOM $[9,10])$. Microorganisms can also organize themselves in the form of a biofilm (aggregates of organized microbial communities held together by the polymers they excrete), which makes the bacterial population more resistant to severe environmental conditions or to variations in these conditions $[5,11-13]$.

\subsection{Main types of interactions \\ between microorganisms and building materials}

\subsubsection{Biodeterioration}

In many cases, microorganisms have detrimental effects on the structures and construction materials which compose them. In aggressive aqueous media such as waste waters, ground waters, sea waters, agricultural or agro-industrial environments, and industrial effluents, structures - often made of concrete-can suffer deterioration linked to the activity of microorganisms [14-20]. The main microorganisms responsible for biodeterioration are bacteria and fungi. Bacteria are unicellular microorganisms that can exhibit all types of metabolisms. Fungi are uni- or multi-cellular heterotrophic microorganisms: they need organic matter as a carbon source and electron donor, which means that they generally develop in rich organic carbon environment or on a primary layer of autotrophic microorganisms in the case of environment with low organic matter content [21, 22]. Multicellular fungi produce thin filamentous structures called hyphae, which absorb nutrients in the environment [5]. These microorganisms act on the structures through their metabolism. They produce metabolites, many of which are chemically aggressive to building materials and especially concrete (organic and mineral acids, $\mathrm{CO}_{2}$, sulfur compounds, etc.) [2326]. They can also degrade materials through some specific effects, such as the formation of biofilms on the surface, which locally generate high concentrations of aggressive metabolites [27], or the physical action of hyphae of fungi on the material [22, 28, 29]....The deterioration occurring in concrete materials in connection with mineralogical, microstructural and chemical changes is as varied as loss of alkalinity, erosion, spalling of the concrete skin, corrosion of rebars, loss of water- or airtightness, and collapse [18, $30,31] \ldots$. Such deterioration leads to a significant increase in the direct cost of repairing structures and indirect costs linked to loss of production income (e.g. during repair work inside damaged plants), and may also lead to pollution resulting, for example, from waste water leakage to the environment (case of damaged infrastructures intended for collecting or storage of effluents). A case in point is the risk of damage to repositories intended for nuclear waste storage, by microbial action on the geological and chemical conditions within the infrastructures [2, 4]; this will be developed further in this paper.

\subsubsection{Microbial stains on building materials}

Microorganisms can also act on structures through their own appearance. The facades of buildings or monuments can be subject to proliferation by colored microorganisms. These are mainly algae or 
cyanobacteria, which are photoautotrophic microorganisms, i.e. they use light as their energy source and mineral compounds as carbon source $\left(\mathrm{CO}_{2}\right)$ and electron donors (photosynthesis). They can thus grow on strictly mineral supports such as stone, roofing tiles and concrete or cementitious coatings (with lowered $\mathrm{pH}$ following carbonation or other chemical weathering), etc. The consequences are mainly aesthetic: green, black or red stains develop, sometimes very quickly, on infrastructures, depending on a variety of climate, environmental and architectural parameters $[3,32-36]$. Fungi can also participate in this kind of attack. In this case, beside aesthetic alterations, building materials can suffer mineralogical and microstructural damage [29, 37]. The biological stains lead to significant cleaning costs and to image prejudice in the case of prestigious buildings. Although the microorganisms responsible for these alterations have been quite well identified [32, 38-41], research is now focusing on determining colonization mechanisms, notably the influential material-related factors $[3,35,36,42]$, and on developing preventive or curative solutions to protect external walls [43-47]. However, some research works seek to improve the bio-receptivity of materials in order to favor the growth of microorganisms such as algae or lichens and higher plants that can improve the appearance and the thermal performance of buildings [48].

\subsubsection{Indoor microbial proliferation}

Building materials are also exposed to microbial proliferation in indoor environments Microorganisms thriving in damp indoor environments (molds, bacteria, fungi) are known to be one of the main causes of the degradation of indoor air quality and can be serious health hazards to occupants because of the production of airborne particles such as spores, allergens, toxins and other metabolites. Health troubles include irritations and toxic effects, superficial and systemic infections, allergies and other respiratory and skin diseases [49]. The resulting social and economic impact is very significant $[50,51]$. The surfaces of building materials (plasterboard, mortar, etc.) are generally highly porous and rough. In damp environments, these materials can provide an support favorable to the proliferation and growth of microorganisms. Although the microorganisms that develop in building environments are quite well identified for conventional building materials, studies linking the properties of these materials with the nature of the proliferation in terms of species and kinetics are still lacking in the literature [49]. Current research work notably aims to develop different solutions to inhibit, or at least, reduce microbial proliferation on building materials and substrates [52-57]. Moreover, the literature on the susceptibility of bio-based materials, incorporating plant aggregates and/or fibers, to microbial proliferation is scarce [58, 59]. This topic needs serious consideration, in particular with the increasing interest in these materials [60-63].

\subsubsection{Positive effects of microorganisms}

However, in some cases, microorganisms can have beneficial effects on cementitious materials, for example when they are used as a way to protect and/ or repair concrete, in applications such as bacteriabased protective systems. New formulations of cementitious materials, incorporating selected bacteria and suitable chemical precursors, are being developed with the aim of filling micro-cracks in concrete and thus improving its durability properties [64, 65]. Surface treatments such as biodeposition are also being explored [66-68]. In other cases, the formation of microbial biofilm on the surface of cement-based materials can provide a protective layer against biological deterioration, e.g. either by the excretion of protective organic polymers (EPS $=$ ExoPolymeric Substances), where beneficial precipitation of calcium carbonate can occur for example [69], or by the proliferation of non-aggressive microbes capable of competing with undesirable microorganisms [70, 71]. Also, the metabolites produced by some fungi or lichens, such as oxalic acid, can protect Ca-bearing materials by the precipitation of calcium oxalate at their surface $[72,73]$.

\subsection{Understanding microorganisms-cementitious materials interactions}

Since concrete is the most widely used building material, understanding the interactions between microorganisms and cementitious materials is crucial and constitutes a fundamental step toward more durable, safer, better quality structures in many contexts. Nevertheless, except for the case of 
biodeterioration in sewer systems $[1,7-9,74]$, these phenomena have only recently been considered by building material and product manufacturers, owners, civil engineers and contractors, and finally, research funders. In the scientific literature, it is also quite a recent topic, the coverage of which has been increasing, especially since the late 1990s. Current unanswered questions pertain to both scientific and technical aspects. Among other things, the specific impact of microorganisms on concrete structures in terms of biodeterioration mechanisms-apart from that of their metabolites-is not well understood. Moreover, the influence of the material properties (chemical and physical) on the activity of the microorganisms and their structuring into biofilm, for example, is not well apprehended, although it conditions the deleterious impact on the material [75]. Moreover, no standard test method exists to qualify concrete or building materials exposed to the action of microorganisms. So, current research is interested in developing relevant, rational and representative test methods in the various contexts concerned [27, 33, 34, 76-81]. The modeling of interactions between cementitious materials and the microorganism-bearing environment is also in its early stages. It is, however, a high-priority issue to complete the understanding of these interactions on the one hand and to predict the material/product/structure service life duration on the other. The double challenge is to model (i) the activity of microorganisms and biofilm at the surface of a highly reactive material such as concrete and (ii) the impact of specific metabolites $\left(\mathrm{H}_{2} \mathrm{SO}_{4}\right.$, citric acid, etc.) that produce expanding secondary products by reaction with the cementitious matrix, which in turn creates cracking within the matrix and modifies its transfer and mechanical properties.

RILEM Technical Committee 253-MCI-microorganisms cementitious materials interactions, was created in 2013 and aims to address all these issues by bringing together specialists from the different domains (cementitious materials, microbiology, process engineering...). The activity of this TC, which should end in 2018, will include the writing of a State-of-the-Art report in which all the aspects mentioned above will be developed in much greater detail.

The present paper focuses on two types of interactions between microorganisms and cementitious materials that I have had the opportunity to work on.
The first concerns concrete in agricultural and agrofood environments. The aim of this research work was to improve the durability of cementitious materials under the action of both chemical and biological attacks induced by agro-industrial media (agro-food, agricultural and breeding effluents, mainly). Mechanisms of concrete alteration in these environments were investigated. In particular, chemical attack of cementitious materials by organic acids, which are quite common microbial metabolites, was thoroughly explored. The impact of microorganisms on the alteration mechanisms and kinetics was also investigated. The second type of interaction concerns a little known aspect of the safety of nuclear waste repository structures, at least from the civil engineering standpoint: the possible influence of microbial activity on the redox conditions within the cells intended for intermediate-level long-lived nuclear wastes. Both studies have notably focused on the development of laboratory pilots to rationally investigate the interactions among microorganisms, materials and chemical species in controlled microbial conditions. The paper also aims to point out current shortcomings in the scientific literature and in the standardization environment.

\section{Biodeterioration of concrete structures in agricultural and agrofood environments}

\subsection{Context and problems}

In their initial state, agricultural effluents, such as liquid manure, molasses, silage juices and effluents from biogas systems, contain, among other species, more or less complex organic matter (including organic acids), and microorganisms (bacteria, yeast). The activity of these microorganisms can degrade the organic compounds and, in turn, produce organic acids (acetic, lactic, succinic) together with $\mathrm{CO}_{2}$ and $\mathrm{CH}_{4}$. The various acids found in these effluents are thus either produced by this bacterial activity or are contained in the raw materials (fruit or plants in the case of molasses and wine effluents), or they result from industrial treatments applied to the raw matter at the different steps of the industrial process. The concentration of acids can reach several millimoles per liter depending on the effluents, the $\mathrm{pH}$ of most effluents being between 4 and 8 [26]. 
The effluents lead to serious degradation of the structures intended for their production, collection, storage and processing, which are often made of concrete (cowsheds, housing structures, milking rooms, anaerobic digesters, etc.) [16, 18, 30, 82, 83]. Progressive erosion of the concrete has been observed, which may be accelerated by mechanical action (high pressure cleaning, animal and machine traffic...). In the long term, embedded reinforcement can become corroded and result in the destruction of facilities [30]. The financial and environmental consequences of the damage were mentioned in the introduction.

The aggressiveness of agro-food effluents toward concrete structures is linked to their chemical components (organic acid and $\mathrm{CO}_{2}$ in particular), on the one hand, and to their microbiological components, on the other hand [16, 27, 83]. Developing concrete that perform well in such environments necessitate to understand the degradation mechanisms by the various aggressive compounds contained in the effluents. Our strategy was to separate chemical and biological phenomena and to use model media: synthetic organic acids [84-86] on the one hand, and model microbial environments [27] on the other. Studies were then validated using real effluents (liquid manure, silage juices, biogas system juices) [16]. The first part of this report will concern research work focusing on attack by organic acids and the second part will look into biological action in such media.

\subsection{Attack by organic acids}

Aggressive media consist of mixes of a wide range of organic acids where the chemical and physical properties of the acids and of their salts and organometallic complexes are many and varied [26, 87]. In order to move toward an approach predicting the aggressiveness of such or such medium according to its acid composition, the work aimed to identify the relationships between the aggressiveness of the acids, the physical and chemical properties of the acids and their salts, and the chemical and mineralogical properties of the cement matrix. Works were first carried out with acids taken separately [84-86, 88, 89] before mixes of acids were considered [90, 91]. One of the aims was also to identify the resistance of ordinary and special binders in such environments [92, 93]. The work was based on experiments and modeling. Mineralogical, chemical and microstructural changes were studied using various analytical techniques for liquids and solids, the results of which were crosscompared to establish the alteration mechanisms [85, 94]. The influence of some parameters and/or phenomena such as polyacidity or complexation being difficult to highlight experimentally, equilibriums in solutions were also investigated using CHESS and HYTEC software on a wide range of $\mathrm{pH}$ and concentrations. Particular attention was paid to the formation of complexes in solution $[87,90]$.

\subsubsection{Mechanisms and kinetics of degradation by the acids}

The kinetics of cement paste alteration varies greatly from one acid to another (Fig. 1). Immersion of cement pastes in synthetic organic acid solutions with the same concentration of acids showed that: (i) the most aggressive of the acids tested was citric acid (pH4) which dissolved a 25-mm-diameter cement paste specimen in less than 4 months, (ii) the least aggressive of the acids tested was oxalic acid, despite the very low $\mathrm{pH}$ of the acid solution (0.85). This example showed that the $\mathrm{pH}$ parameter is not sufficient to characterize the aggressiveness of an acid medium.
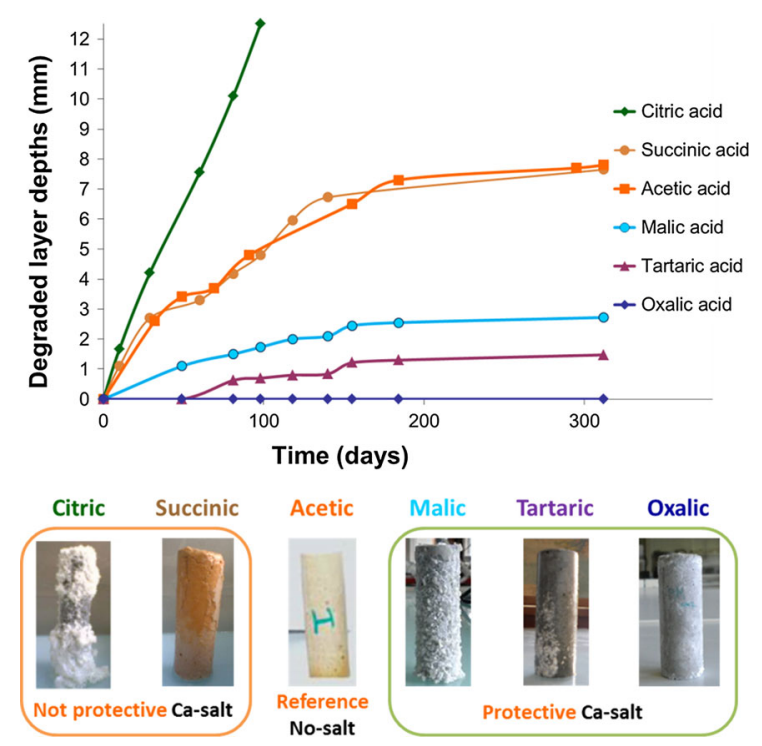

Fig. 1 Kinetics of alteration of various organic acids toward Portland cement paste [26] and aspects of the corresponding specimens. All the acid solutions were $0.28 \mathrm{M}$ and with a $\mathrm{pH}$ of 4 (adjusted by addition of soda), except for the oxalic acid solution, the $\mathrm{pH}$ of which was 0.85 
The composition of acids of the medium should be considered in any attempt to predict its aggressiveness. It should be noted that $\mathrm{pH}$ is, however, the main criterion to be considered in NF EN 206-1 (2004) and FD P 18-011 (2009) for the classification of aqueous acid environments. Finally, two groups of acids can be considered: (i) acids with soluble calcium salts (no formation of salt occurs during the attack in usual laboratory conditions, i.e. regular renewal of acid solution or addition of concentrated acid and periodic renewal of solution); (ii) acids with slightly soluble salts. Within the latter group, the formation of the salt in the conditions of the experiments is either protective or destructive for the matrix, depending on the properties of the acids and their salts (Fig. 1).

Acids with soluble salts (acetic acid, propionic, and butyric acids, etc.). These acids are present in most agricultural/agrofood effluents and in many microorganisms-bearing environments (sewer systems, etc.). The alteration mechanisms have been described by several authors [84, 85, 88, 95, 96]. This attack expresses itself by calcium leaching from the matrix and the formation of a Si-Al-skeleton gel with high porosity [85] and very weak mechanical properties. The altered zone is not dissolved during the attack. In this case, the aggressiveness of the acids is related to their pKa [88] and to the chemical and physical properties of the matrix [85] and the aggregates. The attack by acids with soluble Ca-salts is close to that induced by strong acids with soluble salts such as $\mathrm{HNO}_{3}$ or $\mathrm{HCl}$ [24]. These organic acids can advantageously replace strong acids in laboratory experiments as advantage can be taken of the acids' buffer zone (low $\mathrm{pH}$ changes for significant release of $\mathrm{OH}$ - anion by the cement matrix in the $\mathrm{pH}$ interval $[\mathrm{pKa}-1$, pKa + 1]) [97].

Acids with slightly soluble to insoluble salts (oxalic, citric, succinic, tartaric, and malic acids). These acids can be found in agro-food effluents (winery effluents, vinasses, dairy effluents) and in the plants or fruits themselves. Oxalic and citric acids can also be excreted by some fungi or lichens and deteriorate building materials [98-102]. The attack by these acids leads to the formation of Ca-salts. These salts are systematically formed by the reaction between $\mathrm{Ca}$ cations released by the cement paste and the most dissociated form of the acid (in the case of a poly-acid, such as succinic, tartaric or citric acid) [26, 86]. Although the properties of the salt largely determine the intensity of the attack, the mineralogical composition of the matrix also has an influence. Two groups of acids can be distinguished: those having salts that are protective toward the matrix (i.e. the precipitation of the salt reduces the kinetics of the front progression inside the matrix compared to the reference acid: acetic acid) and those having salts that worsen the degradation kinetics. A correlation between the molar volume of the salt and the degradation occurring on the matrix has been observed $[26,86]$. The volume of the paste porosity, and the phases at the expense of which the salt forms, are also influencing parameters. Citric acid, the most aggressive of the acids tested, forms $\mathrm{Ca}$ citrate tetra-hydrate through the reactions with the cement matrix. The molar volume of this salt is very high $\left(518 \mathrm{~cm}^{3} / \mathrm{mol}\right)$ compared to the molar volume of the phases at the expense of which it precipitates, i.e. $\mathrm{C}-\mathrm{S}-\mathrm{H}$ and $\mathrm{Ca}(\mathrm{OH})_{2}\left(125\right.$ and $33 \mathrm{~cm}^{3} / \mathrm{mol}$, respectively). The outer layer of the cement paste is severely damaged by the precipitation of Ca-citrate. The high aggressiveness of citric acid is also assumed to be linked to its tri-acidity: for a given concentration of acid, three moles of hydronium ions are released and participate in the hydrolysis of the cement matrix. The least aggressive acid for cementitious matrices made of ordinary binders is oxalic acid. In the case of oxalic acid, the precipitation of Ca-oxalate, which is hardly soluble, if at all, protects the matrix. In the case of OPC pastes, $\mathrm{Ca}(\mathrm{OH})_{2}$, which dissolves when $\mathrm{pH}$ values are lower than 12.5 , is likely to play a sacrificial role in the attack: $\mathrm{C}-\mathrm{S}-\mathrm{H}$ are preserved and the paste keeps its integrity even in the outer altered layer exposed to $\mathrm{pH}$ as low as 0.85 [86]. In contrast, CEM III pastes with high substitution rates are progressively attacked (but with slow degradation rates): in the absence of $\mathrm{Ca}(\mathrm{OH})_{2}$ in the hydrated matrix, C-S-H are attacked. The highly beneficial effect of Ca-oxalate is probably related to (i) the molar volume of the salt which enables it to fill the volume of $\mathrm{Ca}(\mathrm{OH})_{2}$ and the porosity of CEM I paste and probably a small part of hydrates porosity [86], and (ii) the high stability of this salt over a wide range of $\mathrm{pH}$ and concentrations of acids [87]. It should be noted that the protective effect of oxalic acid toward calcium-bearing stony materials is quite widely reported in the literature [100, 103].

Synthesis of parameters influencing aggressiveness of the acids. Finally, an attempt was made to classify the parameters influencing the aggressiveness of the acids toward cementitious materials (Fig. 2). The 
phenomenology of organic acids' attack is primarily related to the acid salt solubility. When the salt is soluble, the chemical properties of the acids (pKa, polyacidity, as well as the $\mathrm{pH}$ of the solution versus the $\mathrm{pKa}$ [88] ) and the properties of the paste, influence the acid's aggressiveness $[92,95]$. The polyacidity of the acid may also influence its aggressiveness to the cement matrix [87], although no polyacid with soluble Ca-salt has been studied in the literature. Moreover, it is likely that complexation phenomena have an impact on the intensity of the hardened matrix alteration (through a cation-pump effect) but no direct evidence has been provided yet, either from experimental [26] or from modeling studies [104]. Finally, the composition of the cement matrix and notably the chemical stability of the Ca-bearing phases influence the resistance of the matrix to the attack. Ordinary binders with aluminum-rich supplementary cementitious materials (SCM) have been found to offer a good resistance to attack, especially with slag additions [95, $105,106]$. The stability of the anhydrous residual grains toward the acid attack may also influence the resistance of the matrix [84, 85, 88, 107]. In very aggressive conditions (low $\mathrm{pH}$, high concentration of acid), the porosity of the matrix was found to be only a secondary parameter of the resistance of the matrix to the attack by acetic acid [95]. When the salts are slightly soluble to insoluble, as mentioned above, the properties of the salts greatly influence their aggressiveness to the cementitious matrix. A strong correlation was highlighted between the molar volume of the salt-in relation to the porosity of the matrix, and the acid's aggressiveness $[26,86]$. The solubility and stability versus $\mathrm{pH}$ of the salt also influence the intensity of alteration: the very low solubility of Caoxalate salt and its wide stability domain (as a function of $\mathrm{pH}$ and concentration of acid) accounts for its protective effect on the matrix [87] in comparison with Ca-tartrate, for example [26, 108]. Although they are not well understood yet, other salt-related parameters could influence the acid's aggressiveness, such as the affinity of the salt for the matrix, its mesoscopic shape (which should condition its ability to cover the cement matrix and thus protect it against further degradation), or its mechanical properties. The properties of the paste are also major parameter of the acids' aggressiveness and, in the case of acids with little soluble salts, they can act adversely to the case of acids with soluble salts (Fig. 2). For example, the presence of the

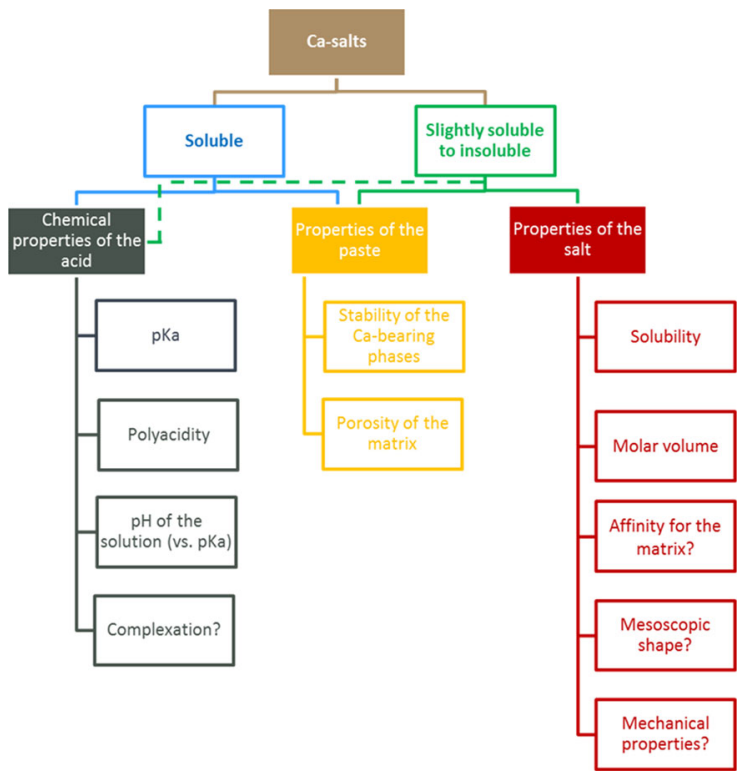

Fig. 2 Organization chart of parameters influencing the aggressiveness of organic acid toward the cement matrix (from experimental and modeling works). The dotted line illustrates secondary influencing parameters (see text)

low stable $\mathrm{Ca}(\mathrm{OH})_{2}$ in the matrix is favorable to the protective effect of oxalic acid (sacrificial role of portlandite which contributes to preserve $\mathrm{C}-\mathrm{S}-\mathrm{H}$ from dissolution) [86]. Also, higher porosity of the cement matrix seems to promote the protective effect of oxalic acid on the cement matrix [91]. Finally, the chemical properties of the acids ( $\mathrm{pKa}$, polyacidity...) seem to play a secondary role in the aggressiveness of acids with slightly soluble to insoluble Ca-salts.

\subsubsection{Performance of cement based materials}

The performance of cement based materials exposed to organic acids, estimated by the kinetics of alteration, can be measured through altered depths, mass losses/gains and variations of mechanical strength for example. Altered depth should be preferred as the prime indicator of resistance as it expresses the time taken for the alteration front to reach reinforcements in the case of reinforced concrete structures (which are commonly encountered in the types of media considered). Mass losses should be considered only as a secondary indicator as they depend, in the case of acids with soluble salts, on the initial $\mathrm{Ca}$ content of the cement matrix. From this point of view, considering 


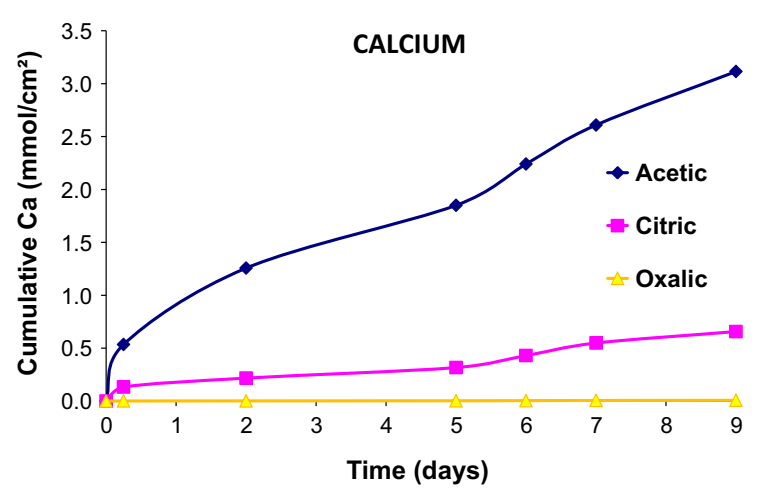

Fig. 3 Kinetics of calcium leaching of Portland cement paste immersed in organic acids [108]. All the acid solutions were $0.28 \mathrm{M}$ and with a $\mathrm{pH}$ of 4 (adjusted by addition of soda), except for oxalic acid, the $\mathrm{pH}$ of which was 0.85 . Leaching of calcium in acetic acid was much higher than in citric acid, although citric acid is much more aggressive to the matrix than acetic acid in terms of altered depths (see Fig. 1). The lower calcium concentration in the citric acid solution made was due to the precipitation of Ca-citrate [86]

mass losses instead of degraded layer depths can lead to significantly different ranking of the resistance of binders because of the different $\mathrm{Ca}$ contents of the materials [92, 97]. The use of mechanical strength testing should also be considered with care: the continuation of hydration in the sound zone can lead to biased results in the estimation of the kinetics of alteration. Moreover, specimens subjected to mechanical tests should be prepared carefully (the zones of loading should be protected from the chemical attack or they should be removed prior to loading in case they have been altered). Finally, estimations of durability should not be made by considering the leaching of calcium only as, depending on the degradation mechanisms, the leaching behavior can give opposite results in terms of acid's aggressiveness to degraded layer depths (Figs. 1, 3). Ideally, a combination of several durability indicators should be used. Several recommendations regarding test methods for cementitious materials exposed to organic acids are made in [97].

Most studies carried out to evaluate the performances of cement pastes toward organic acids have used acetic acid. Not surprisingly, the best performance in such environments was observed with low W/C matrices that contained small amounts of $\mathrm{Ca}$, and large amounts of $\mathrm{Si}$ and $\mathrm{Al}[84,85]$. Supplementary cementitious materials such as slag and metakaolin were found to improve the resistance of the matrix [85, $93,95,106]$. Long curing periods ( $>3$ months) substantially enhanced the resistance of the hydrated phases (slag hydrates were found to preserve their calcium during leaching at $\mathrm{pH}$ as low as 4) [95]. Nevertheless, without this long curing time, in $\mathrm{pH}$ as low as $4 \mathrm{pH}$ at which experimental campaigns are generally conducted) the gain of resistance obtained using SCM was limited. CAC appeared to be the most resistant of the binders tested in these conditions [92, 93]. Few data exist regarding the durability of cement matrices exposed to organic acids with slightly soluble Ca-salts, such as citric or tartaric acids [93]. Alkaliactivated materials could offer good resistance to organic acids [105, 109, 110] but more research data are necessary to identify the benefits of such binders [111].

\subsubsection{Perspectives}

Several aspects deserve attention in further studies on the durability of cementitious materials in organic acids. Regarding the attack by acids with slightly soluble salts, the influence of some properties of salts, not well understood yet, such as the affinity of the salt for the matrix, its mesoscopic shape and its mechanical properties still have to be investigated. The promising behavior of slag based binders should also be confirmed and explained. Moreover, oxalic acid could be explored as a way to protect the cementitious materials against acid environments [91]. Knowledge of the mechanisms of attack in mixes of acids has also to be completed [26, 91, 93]. Finally, geochemical modeling of interactions between organic acids and cementitious matrix should be continued and improved. In particular, attack by organic acids creating expansive salts which generate cracks in the matrix and in turn modify its transfer properties needs to be adequately modeled in order to better predict the service life duration of concrete products and structures subjected to acid environments. It was finally clearly highlighted that $\mathrm{pH}$ should not be considered as the only indicator of aggressiveness of acid environments: the composition of acids should also be considered (nature of acids and concentrations). In this view, standards defining classification of chemically aggressive environments to concrete should be improved. 
2.3 Microorganisms-concrete interactions in biodeterioration processes of agroindustrial environments

Experiments with real media have shown that it is not sufficient to consider synthetic chemical compounds when the aim is to understand and express all the interactions between the materials and medium, in particular when microbial activity is involved [16, 17, 112]. As mentioned in the introduction, microorganisms may have specific effects on the material, for example by the formation of biofilm at the surface, which may worsen degradation compared to the purely chemical attack [16, 27]. Identifying the impact of microorganisms on substrates requires specific laboratory methods. At the moment, there is no standardized method to qualify concrete in microorganism-bearing media. Efforts are made by research groups worldwide to propose such methods. The methods have to be representative of the different environments to be simulated. They generally require specific microbial metabolisms and nutrient supplies, and they have to simulate specific environmental conditions (aerobic/anaerobic, mode of humidity/ water supply: immersion, condensation, capillary ascent, run-off, etc.). Different environments have been considered in the literature so far: sewer systems (attack by biogenic sulfuric acid excreted by SOB) [1, 76-80], external concrete walls exposed to humidity (proliferation of algae or fungi at their surface) [32, $[33,36,113,114]$, etc. For agricultural environments, we proposed a test method aimed at mimicking hydraulic, microbial and chemical conditions occurring in storage silos of agricultural and agro-food effluents and identifying the effect of microorganisms in the degradation [27].

\subsubsection{Test device}

The aim was to develop a test-the Build-Mat Bio test or $B M B$ test-that enabled the specific effect of bacteria to be identified in the alteration of building materials by microorganism-bearing liquid media in immersion conditions. The purpose was to work either with a model environment (isolated or mixed pure strains) or with consortia, under controlled biological and environmental conditions (temperature, nutrients, flow rate, selected microorganisms, etc.). As it is impossible to isolate the bacteria from their metabolites (such as organic acids, $\mathrm{CO}_{2}$, etc.) since they produce them continuously, the idea was to work by difference between a medium containing the bacteria and the metabolites and another medium identical in chemical composition but free of any bacteria thanks to a biomass filter (Fig. 4) [27]. The culture of microorganisms was separated from the exposure to the cement matrix by using a pre-culture in a bioreactor from which the aggressive media were extracted and passed through a column containing the cement matrices. The system was based on dynamic feeding that prevented any accumulation of the cement leachates in the media. In the study case, the test was intended to simulate the quasi static hydraulic conditions occurring in storage silos (liquid manure or silage silos) so very low flow rates were imposed in the system. However, other hydraulic and biological conditions can be simulated with the $B M B$ test.

\subsubsection{Decoupling degradation mechanisms}

The test device was used with the model bacterium Escherichia coli, a common, well-know and easy-togrow bacterium found in many organic effluents. A specification for the device was that the chemical characteristics ( $\mathrm{pH}$ and composition of acids) of the two liquid media circulating in the columns of the BMB test (with and without bacteria) were very close and representative of a liquid manure, the simulated medium in this case $(\mathrm{pH} 8$, total concentration of lactic and acetic acids: $0.12 \mathrm{M}$ ). The mineralogical and chemical changes and the altered layer depths were investigated on the cement paste specimens in the two columns (with and without E. coli). For comparison, cement pastes were exposed to the organic acid compound of the medium using synthetic acetic and lactic acids with same concentrations as in the $\mathrm{BMB}$ test and by adjusting the $\mathrm{pH}$ to 6 (using $\mathrm{NaOH}$ ) (Fig. 5).

It was found that the least severe attack came from the synthetic acids alone (with the lowest $\mathrm{pH}$ of the three media considered). The depth of the degraded layer of the paste was $0.2 \mathrm{~mm}$ after 4 weeks of exposure. In the $B M B$ test, the degraded layer was twice as deep in the presence of bacteria $(1.3 \mathrm{~mm})$ as in their absence $(0.65 \mathrm{~mm})$. Moreover, EPMA and XRD analyses showed that the outer layer of specimens exposed to bacterial cells were completely decalcified and amorphous whereas quite intense 
Fig. 4 Schematic diagram of the Build-Mat Bio-test (BMB test) [27]
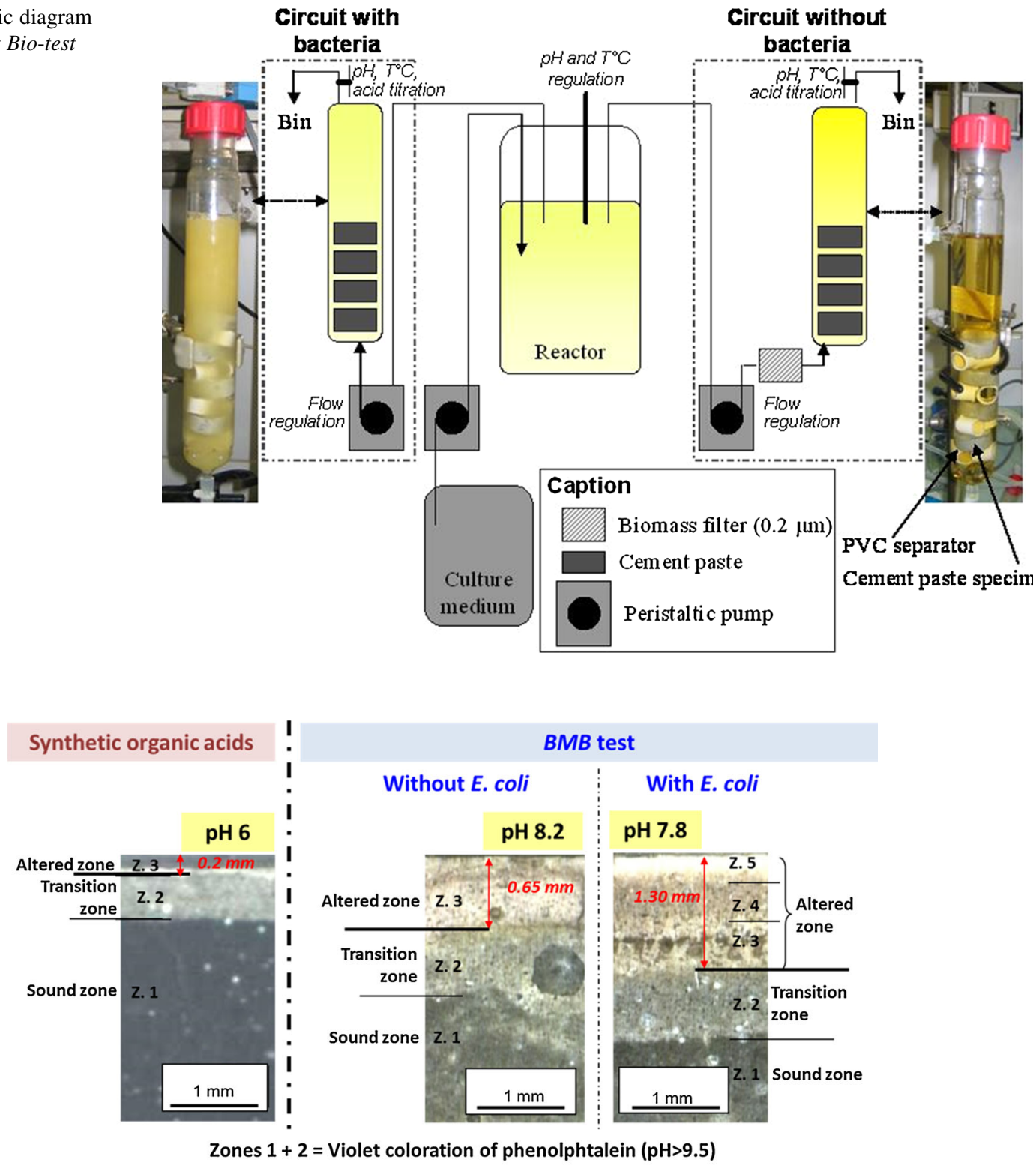

Fig. 5 Cross sections of cement paste specimens exposed to the $B M B$ test for 4 weeks (column with and without bacteria) and to synthetic organic acids in the same hydraulic conditions. The upper zone of the pictures matches the surface of the specimen

carbonation and only partial decalcification was identified in the outer zones of cement pastes exposed to the metabolites only. This highlighted not only the supplementary effect of bacterial respiration (compared to the acid constituents alone) but also, and most importantly, the influence of the formation of biofilm at the surface of the specimens in the column with in contact with the aggressive media (corresponding $\mathrm{pH}$ given in the yellow rectangles). The lower parts of the pictures match the cores of the cement specimens (cylinders $25 \mathrm{~mm}$ in diameter). Adapted from [27]

bacteria, which markedly intensified degradation. These results show that considering only the chemical compounds of the bacteria-bearing media leads to an underestimation of the alteration in terms of its intensity and kinetics. The ability of bacteria to form biofilms at the surface can become really detrimental to structures and these aspects must be taken into 
account when evaluating the durability of materials, products and structures in such environments.

\subsubsection{Perspectives}

As mentioned above, there is currently a lack of standardized test methods for qualifying concrete in microorganism-bearing environments. Progress should be made in the coming years, notably on the basis of test methods proposed in the scientific literature. It should be kept in mind that the test methods have to be specific to the type of environment considered. Moreover, prescriptions for concrete formulation in such environments must also be adapted to take better account of the specificity of biodeterioration. Regarding interactions between microorganisms and cementitious materials, while the mechanisms of alteration of the cement matrix should be further completed in the different contexts where biodeterioration occurs, the impact of the cement paste properties (chemical, mineralogical, physical) on the biofilm structuration and activity also has to be investigated as, in some cases, it plays a significant role in the durability of the cement based materials and products $[75,76$, $115,116]$.

\section{Bio-geo-chemical interactions and reactivity of nitrates in nuclear waste repository}

\subsection{Context and issue}

Deep repository of nuclear wastes is an unexpected context where microbial activities and their interactions with materials deserve attention because these interactions can significantly influence the geo-chemical conditions - and thus the safety-of the storage. In France, a significant fraction of intermediate-level, long-lived radioactive wastes (IL-LLW) consist of a mixture of inorganic salts immobilized in a bitumen matrix. They are poured into steel containers grouped in reinforced concrete over-packs that will then be placed inside concrete waste cells built at a depth of 450-550 within a Callovo-Oxfordian clay host rock formation [117]. After closure of the cells, water resaturation should enhance the release of chemical species into the interstitial aqueous medium. These include soluble salts (notably nitrates or sulfates) and organic matter such as organic acids, phenols, etc. contained within the bituminous matrix [118], together with gas (mostly $\mathrm{H}_{2}$ ) produced via anaerobic corrosion of the steel and/or radiolysis of organic matter and water in the repository (Fig. 6). However, the presence of nitrates $\left(\mathrm{NO}_{3}{ }^{-}\right)$and other oxidized species (such as $\mathrm{SO}_{4}{ }^{2-}, \mathrm{Fe}^{3+}$, and $\mathrm{CO}_{2}$ ) in the vicinity of waste packages may result in oxidizing conditions favorable to the mobility of a series of radionuclides (Se, U, Tc, Pu, Np, etc.) [2]. However, in the geochemical conditions prevailing in the cells (notably anoxic, after depletion of oxygen, and highly alkaline, imposed by concrete leaching) different redox reactions are likely to occur driving the system back to a reducing environment favorable to the safety of the repository. Among these reactions, nitrates reduction will play a key role in the cell since reactions at high $\mathrm{pH}$ necessitate a high energy contribution. Reduction of nitrate $\left(\mathrm{NO}_{3}{ }^{-}\right)$may occur (i) from surface catalysis provided by the different types of steels in the waste cell, and/or (ii) from biological catalysis through bacterial activity [119-121]. Microbial investigations of candidate host rocks intended for deep nuclear waste repositories in France and Switzerland have highlighted small viable communities, these microorganisms being almost dormant (inactive) because of very limited space and water availability (low porosity of the unperturbed rock formations) [122-125]. Nevertheless, the repository excavation and construction works may allow further development of microbial communities in the cell, (i) either by

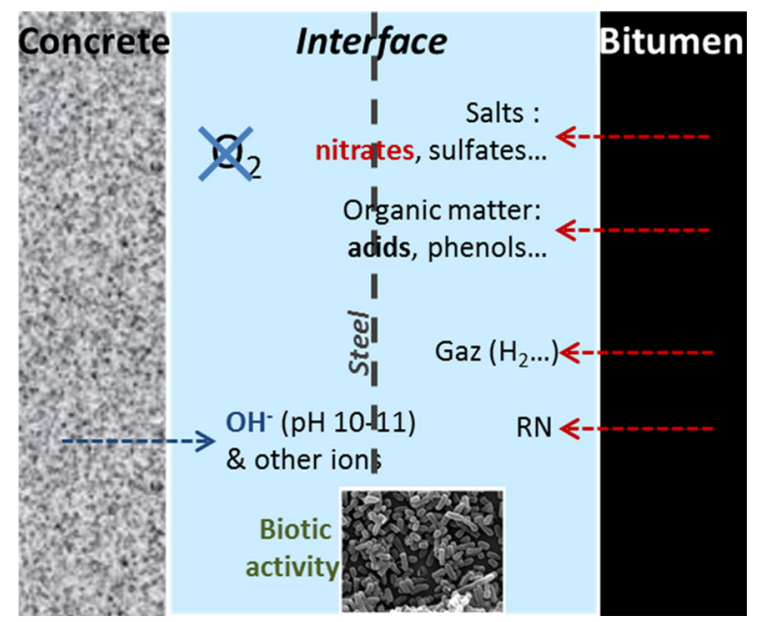

Fig. 6 Schematic representation of the physico-chemical conditions at the concrete bitumen interface in the disposal cells of IL-LLW (adapted from [129] ) 
proliferation of the indigenous microbial population from the surrounding host rock after disturbances that will provide space, water and nutrients, likely to revive the dormant organisms and/or (ii) by contamination by non-indigenous microorganisms brought by human activities during the construction and exploitation of the cells before their closure. Moreover, studies on natural analogues (such as sediments from a lime working site or from a soda lake) have shown that microbial activities are possible in highly alkaline $(\mathrm{pH}$ up to 12-13) and anaerobic chemical environments similar to those which should develop in a nuclear waste deep repository [126-128].

The reactions involving nitrates-whether they be abiotic or biotic i.e. without or with bacteria-may lead to the formation of nitrite $\left(\mathrm{NO}_{2}{ }^{-}\right)$, nitrogen $\left(\mathrm{N}_{2}\right)$ and/or ammonium $\left(\mathrm{NH}_{4}{ }^{+}\right)$, depending on a variety of parameters not well understood yet, particularly in the alkaline conditions imposed by the surrounding concrete. Both types of reduction reactions involve electron donors and numerous candidates are available in the waste cell or in the host rock (organic acids, $\mathrm{H}_{2}$, zero-valent metals, ...) [2]. The overall study aims to investigate the reduction of nitrates within a system comparable to a "real" waste-cell where bacterial activity is likely to occur (denitrifying alkalophilic bacteria, in the conditions considered here) and notably to determine the phenomenology and kinetics of reactions and the role of each potential electron donor (i.e. organic acids released by bitumen, such as acetic or oxalic acids, $\mathrm{H}_{2}$, the various metallic phases in the repository, etc.) in the reactions [129-131]. The environment under consideration is complex, multicomponent and multi-phase. A step-wise approach was thus adopted, starting with simplified decoupled model systems (model media studied in batch conditions) $[129,130,132]$, the complexity of which was progressively increased to move to close-to-real systems using an experimental pilot specifically developed for the study [131].

It should be noted that, apart from the problem considered here regarding the fate of oxyanions such as nitrates, there are other types of possible interactions between microorganisms and the various chemical compounds and materials (concrete, bitumen, metal, clay rock, etc.) within the nuclear waste repository that pertain to microbiologically induced corrosion (MIC) [4, 120, 133-137]. Moreover, microorganisms can modify the fate of radionuclides themselves [138, 139]. All these aspects show that microbial activities should be taken into account when predicting the geochemical conditions in the repository cells and evaluating how safe the storage will be.

\subsection{Physicochemical interactions under abiotic conditions}

Physical and chemical interactions between the various compounds of interest in the systems (nitrates, bitumen leachates, concrete, and steel) were first studied in the absence of bacteria, in order to decouple abiotic and biotic phenomena likely to occur in the repository.

Among the organic matter released by bitumen of IL-LLW, short-chain organic acids (notably acetic, formic and oxalic acids [118, 140-143])-easily assimilable by bacteria in the repository-are likely to react with concrete of the repository). These reactions may, on the one hand, alter the durability of concrete cells [84, 88, 129, 132, 144], and, on the other hand, change the availability of organic matter usable by heterotrophic microorganisms for the reduction of oxyanions such as nitrates. It should also be noted that other sources of organic acids than bitumen can be found in nuclear waste storage: when cellulosic materials are immobilized with other lowand intermediate level radioactive wastes in cement matrices, cellulose may degrade, mainly to isosaccharinic acid, but also to formic and acetic acids following the reactions of polymers which break down under alkaline conditions [145, 146].

Beside acid-cement paste interactions, investigations have also focused on the reactivity of nitrates under abiotic conditions. The reduction of nitrates has been proved to be possible in the presence of different types of steels, in conditions similar to those occurring in a repository (i.e. alkaline $\mathrm{pH}$ and anoxic conditions), and it leads to the formation of $\mathrm{NH}_{4}{ }^{+}$. At $\mathrm{pH}$ up to about 11.5 , nitrates can be reduced in the presence of $\mathrm{C}$-steel, but the reaction rates strongly decrease when $\mathrm{pH}$ increases. In this case, carbon steel is likely to act as the electron donor [121, 131, 147], visible signs of corrosion being observed at the steel surface. Stainless steel, also present in the repository, could be involved in nitrate reduction, up to $\mathrm{pH} 12$, in the presence of $\mathrm{H}_{2}$ gas as an electron donor. In this case, stainless steel act as a real surface catalyst, i.e. no corrosion of steel occur [148, 149]. 


\subsection{Interactions under biotic conditions}

Microbial denitrification transforms nitrates to gaseous nitrogen via several intermediates, notably nitrites: $\mathrm{NO}_{3}{ }^{-}$(aq.) $\rightarrow \mathrm{NO}_{2}{ }^{-}$(aq.) $\rightarrow \mathrm{NO}_{\text {(enzyme complex) }} \rightarrow \mathrm{N}_{2-}$ $\mathrm{O}_{\text {(gas) }} \rightarrow \mathrm{N}_{2 \text { (gas) }}$ [150]. Microbial denitrification, in the particular context of the disposal of radioactive waste as defined in Fig. 6, has so far been a matter of pure speculation. However, many microorganisms are known to lead to denitrification under conditions similar to those likely to occur in the repository, i.e. notably at high $\mathrm{pH}$ (in the range of $\mathrm{pH}$ 9-11) and anoxic conditions (conditions that will prevail in the storage in the long term). Works carried out to explore the biologically induced reduction of nitrates in such conditions have considered selected pure strains and wild consortia (using natural analogs) [120, 129, 131, 151-154]. The first step of such studies was therefore to identify microorganisms capable of (i) growing in alkaline conditions, (ii) using nitrate as electron acceptor and (iii) using one or more electron donors present in the repository. Two types of electron donors in the repository are explored in the literature: organic acids $[129,131,152-154]$ and $\mathrm{H}_{2}[120,153]$. Bacteria using organic carbon (organic acids here) as substrates and energy source are called heterotophic, whereas bacteria using $\mathrm{CO}_{2}$ as carbon source and chemical compounds such as $\mathrm{H}_{2}$ as electron donor are said to be autotrophic.

Among heterotrophic alkalophilic denitrifying bacteria, Halomonas desiderata $(H d)$ [155] has been identified as an interesting candidate as this bacteria has been shown to reduce nitrates at $\mathrm{pH}$ up to 10 in batch and planktonic (bacterial cells in suspension) conditions [129, 130]. Moreover, the presence of cement matrices was shown to enhance denitrification kinetics at $\mathrm{pH} 10$ (compared to experiments without solid cement matrices) and enabled denitrification reactions at $\mathrm{pH}$ between 10 and 12 , which was taken to be linked to the ability of the bacteria to form a biofilm at the surface of solid CEM V cement paste matrices (Fig. 8a) [129]. In addition to these exploratory experiments carried out in batch conditions, a specific experimental device was implemented to simulate conditions close to those in the repository. The system consisted of a central bioreactor-where selected bacteria were grown - and separate exposure chambers containing cement paste matrices connected in series upstream and/or downstream of the bioreactor. The system was continuously fed with nitrate solution enriched or not with some culture medium. The system was intended to simulate various scenarios likely to occur in the repository [151] and to refine the understanding of microorganism denitrification strategies (calculation of microbial reaction rates in steadystate conditions). In particular, the configuration of the pilot device presented in Fig. 7 explored the impact of alkaline interstitial aqueous medium on the denitrification reaction by planktonic microorganisms (in the bioreactor) and then the impact of the presence of solid cement paste matrices and thus of adhered biomass (or biofilm) on the reactions (in the exposure chamber downstream). The experiments carried out either with enriched medium or with limited-nutrient medium

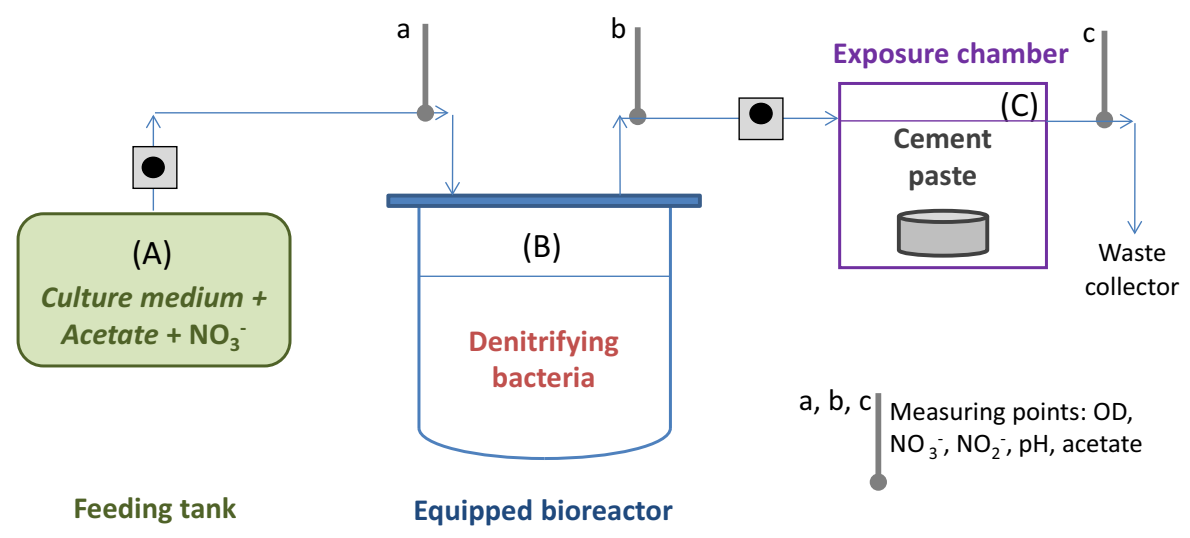

Fig. 7 Schematic representation of the experimental device used for the study of interactions between microorganisms and solid materials during continuous microbial denitrification.
Arrows indicate the direction of the advective flow in the system. b, c temperature $=37{ }^{\circ} \mathrm{C}$; stirring $=300 \mathrm{rpm}[131]$ 

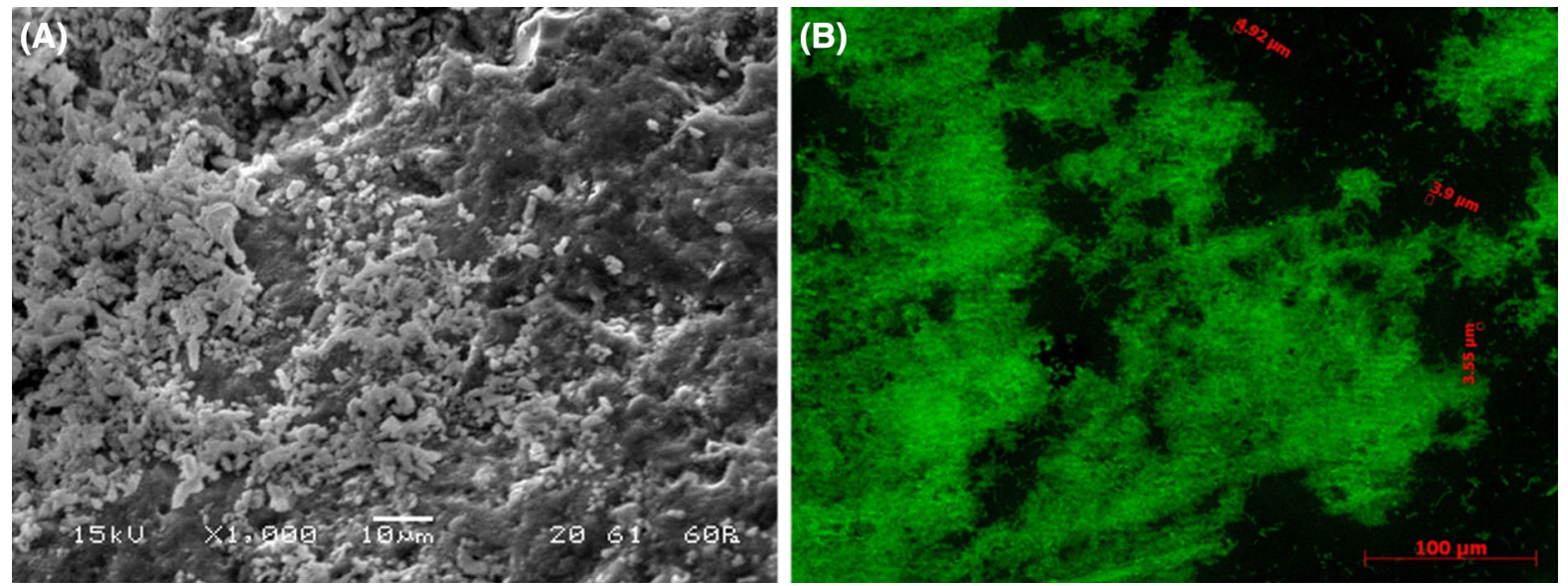

Fig. 8 Microscopic observation of the surface of solid matrices colonized by $H d$ (at $\mathrm{pH} 12$, after $600 \mathrm{~h}$ of exposure): a SEM and b epifluorescence [131]

made of cement leachate and with acetate as electron donor showed denitrifying activity of $H d$ up to a feeding medium $\mathrm{pH}$ of 12 [131, 151]. The denitrifying reactions were improved in the exposure chamber compared to the those occurring in the bioreactor (complete reduction of nitrate to $\mathrm{N}_{2}$, consumption of intermediate nitrites in the exposure chamber) presumably because of the formation of biofilms (Fig. 8b) at the surface of the cement paste specimens: the planktonic (in suspension) cells were inhibited at $\mathrm{pH}$ 12 , whereas cells in biofilm at the surface of cement paste were still active. This organization of bacterial cells in an attached three-dimensional architecture allows them to avoid wash-out and possibly to resist difficult chemical conditions better [11-13].

Finally, the rates of biologically induced nitrate reduction recorded in biotic experiments were much higher than those measured under abiotic conditions (steel catalysis), although the two experimental campaigns were carried out in very similar chemical conditions [131]. These results highlighted the importance of biologically catalyzed reactions and the need to consider them in evaluating the fate of nitrates in radioactive waste repositories.

\subsection{Perspectives}

Further study will explore the possible synergy phenomena between steel surface catalysis and biological catalysis of nitrate reduction. It will also evaluate $\mathrm{H}_{2}$ as an electron donor for microbial catalysis of nitrate reduction in much more details.

On the basis of these experimental results, microbial activity and its influence on the reactivity of several oxyanions and radionuclides in the cell is being modeled [156-158].

\section{Concluding remarks}

Interactions between building materials and microorganisms can occur in many contexts and these interactions can condition the durability, the safety or the aesthetics of numerous buildings and infrastructures. It has been shown, notably through the two examples presented in this paper, that the phenomena occurring in such environments cannot be assimilated to the purely chemical or geo-chemical reactions that they may comprise. One technological issue is the development of test methods that enable the mechanisms of the interactions to be identified and the performances of building materials to be qualified, under representative conditions. This is currently the subject of several research projects, focusing on different contexts of Construction. The test methods should be specific of the environmental conditions considered. Standards have now to evolve to take better account of the building material-microorganism reactions, both from the point of view of test methods and from that of formulation prescription (in 
particular, regarding concrete). Among the main scientific issues to be tackled in the next few years, progress still has to be made in the understanding of biodeterioration mechanisms and the influence of biofilm in the intensity and kinetics of alteration. But the impact of the material properties on the activity of microorganisms and their structuration into biofilm for example is very important and very poorly understood as yet, despite the fact that it can condition the durability of the materials and products. These aspects are crucial steps in the development of building materials that perform well in such environments. This is the aim of the RILEM TC 253-MCI, recently created to deal with all these aspects and also with other topics such as bacteria-based protective systems or indoor microbial proliferation. Finally, one constant challenge inherent in research on microorganismbuilding material interactions stems from its need for multidisciplinary teams involving microbiologists, civil engineers, chemists, process engineers, etc. This constant dialog between researchers of different skills, which is absolutely necessary if we are to understand each other and if our research is to progress, makes it incomparably fascinating and rewarding.

Acknowledgments I would like to acknowledge all my colleagues, researchers in material science, civil engineering, microbiology, pharmacology, process engineering, geology and analytical chemistry, with whom I have had the good fortune to work and collaborate. I thank Prof. Gilles Escadeillas, who was my $\mathrm{PhD}$ supervisor, for showing me the promising and most interesting subject of living-mineral interactions. Thank you for all the rich scientific exchanges and ideas. I am deeply grateful to my colleagues Dr. Benjamin Erable, Prof. Etienne Paul, Dr. Matthieu Peyre Lavigne, Prof. Christine Roques for sharing knowledge and spending time to listen to and understand each other. This is the cornerstone of our join work at the frontier of our respective disciplines. I thank my colleagues and friends at LMDC (UPS/INSA Toulouse) Dr. Marie Coutand, Dr. Camille Magniont, Dr. Vanessa Mazars and Dr. Laurie Buffo-Lacarriere for daily work in common. I acknowledge the work of present and former Ph.D. students and Post-doctoral fellows involved in this research: Dr. Steeves Larreur-Cayol, Dr. Thomas Martinez, Mr. Thomas Verdier, Ms. Célestine Voegel, Mr. Peter Mikhailenko, Mr. Alexis Simons, Dr. Caroline Kassim, Dr. Harifidy Ranaivomanana, Dr. Yan Rafrafi... Finally, I acknowledge my academic and industrial research funders: University of Toulouse, INSA Toulouse and Paul Sabatier University, Région Midi Pyrénées, FUI DGCIS and OSEO, LRVision (Many thanks to Prof. Erick Ringot for initiating research works on photocatalysis), Andra (Special thanks to Dr Achim Albrecht) and Saint-Gobain PAM. I thank my colleagues of the first RILEM TC I was involved in, TC 211-PAE, and notably Prof Mark Alexander and Prof. Nele De Belie, as well as my colleagues of the current TC 253-MCI, especially Dr H Jonkers, Secretary of the TC.

Open Access This article is distributed under the terms of the Creative Commons Attribution License which permits any use, distribution, and reproduction in any medium, provided the original author(s) and the source are credited.

\section{References}

1. Sand W, Bock E (1984) Concrete corrosion in the Hamburg sewer system. Environ Technol Lett 5(12):517-528

2. Albrecht A, Bertron A, Libert M (2013) Microbial catalysis of redox reactions in concrete cells of nuclear waste repositories: a review and introduction. In Bart F, Cau-diCoumes C, Frizon F, Lorente S (eds) Cement-based materials for nuclear waste storage. Springer New York, pp 147-159

3. Dubosc A, Escadeillas G, Blanc PJ (2001) Characterization of biological stains on external concrete walls and influence of concrete as underlying material. Cem Concr Res 31(11):1613-1617

4. Libert M, Schütz MK, Esnault L, Féron D, Bildstein O (2014) Impact of microbial activity on the radioactive waste disposal: long term prediction of biocorrosion processes. Bioelectrochemistry 97:162-168

5. Prescott LM, Harley JP, Klein DA (2003) Microbiologie. De Boeck Supérieur, Brussels

6. Juretschko S, Timmermann G, Schmid M, Schleifer K-H, Pommerening-Röser A, Koops H-P, Wagner M (1998) Combined molecular and conventional analyses of nitrifying bacterium diversity in activated sludge: Nitrosococcus mobilis and nitrospira-like bacteria as dominant populations. Appl Environ Microbiol 64(8):3042-3051

7. Parker CD (1945) The corrosion of concrete-1. The isolation of a species of bacterium associated with the corrosion of concrete exposed to atmospheres containing hydrogen sulphide. Aust J Exp Biol Med Sci 23(2):81-90

8. Parker CD (1945) The corrosion of concrete-2. The function of thiobacillus concretivorus (nov. Spec.) In the corrosion of concrete exposed to atmospheres containing hydrogen sulphide. Aust J Exp Biol Med Sci 23(2):91-98

9. Islander R, Devinny J, Mansfeld F, Postyn A, Shih H (1991) Microbial ecology of crown corrosion in sewers. J Environ Eng 117(6):751-770

10. Roberts D, Nica D, Zuo G, Davis J (2002) Quantifying microbially induced deterioration of concrete: initial studies. Int Biodeterior Biodegrad 49(4):227-234

11. Costerton JW, Lewandowski Z, DeBeer D, Caldwell D, Korber D, James G (1994) Biofilms, the customized microniche. J Bacteriol 176(8):2137-2142

12. Davies DG, Parsek MR, Pearson JP, Iglewski BH, Costerton JW, Greenberg EP (1998) The involvement of cellto-cell signals in the development of a bacterial biofilm. Science 280(5361):295-298

13. Mah TF, O'Toole GA (2001) Mechanisms of biofilm resistance to antimicrobial agents. Trends Microbiol 9(1):34-39 
14. Wang D, Cullimore R, Hu Y, Chowdhury R (2011) Biodeterioration of asbestos cement (AC) pipe in drinking water distribution systems. Int Biodeterior Biodegrad 65(6):810-817

15. Leemann A, Lothenbach B, Hoffmann C (2010) Biologically induced concrete deterioration in a wastewater treatment plant assessed by combining microstructural analysis with thermodynamic modeling. Cem Concr Res 40(8):1157-1164

16. Bertron A, Coutand M, Cameleyre X, Escadeillas G, Duchesne J (2006) Attaques chimique et biologique des effluents agricoles et agroalimentaires sur les matériaux cimentaires. Matér Technol 93:s111-s121

17. Alexander MG, Fourie C (2011) Performance of sewer pipe concrete mixtures with portland and calcium aluminate cements subject to mineral and biogenic acid attack. Mater Struct 44(1):313-330

18. De Belie N, Richardson M, Braam CR, Svennerstedt B, Lenehan JJ, Sonck B (2000) Durability of building materials and components in the agricultural environment: part I, the agricultural environment and timber structures. J Agric Eng Res 75(3):225-241

19. Wells T, Melchers RE (2014) An observation-based model for corrosion of concrete sewers under aggressive conditions. Cem Concr Res 61-62:1-10

20. Herisson J, van Hullebusch ED, Moletta-Denat M, Taquet P, Chaussadent T (2013) Toward an accelerated biodeterioration test to understand the behavior of Portland and calcium aluminate cementitious materials in sewer networks. Int Biodeterior Biodegrad 84:236-243

21. Warscheid T, Braams J (2000) Biodeterioration of stone: a review. Int Biodeterior Biodegrad 46(4):343-368

22. Gaylarde CC, Morton LHG (1999) Deteriogenic biofilms on buildings and their control: a review. Biofouling 14(1):59-74

23. Alexander M, Bertron A, De Belie N (eds) (2013) Performance of cement-based materials in aggressive aqueous environments, RILEM TC 211-PAE. Springer, Berlin

24. Duchesne J, Bertron A (2013) Leaching of 3s ( $\mathrm{HCl}$ and $\mathrm{HNO}_{3}$ ). In: Alexander M, Bertron A, Belie ND (eds) Performance of cement-based materials in aggressive aqueous environments. Springer, Dordrecht, pp 91-112

25. Menéndez E, Matschei T, Glasser FP (2013) Sulfate attack of concrete. In: Alexander M, Bertron A, Belie ND (eds) Performance of cement-based materials in aggressive aqueous environments. Springer, Dordrecht, pp 7-74

26. Bertron A, Duchesne J (2013) Attack of cementitious materials by organic acids in agricultural and agrofood effluents. In: Alexander M, Bertron A, Belie ND (eds) Performance of cement-based materials in aggressive aqueous environments. Springer, Dordrecht, pp 131-173

27. Magniont C, Coutand M, Bertron A, Cameleyre X, Lafforgue C, Beaufort S, Escadeillas G (2011) A new test method to assess the bacterial deterioration of cementitious materials. Cem Concr Res 41(4):429-438

28. Gu J-D, Ford TE, Berke NS, Mitchell R (1998) Biodeterioration of concrete by the fungus Fusarium. Int Biodeterior Biodegrad 41(2):101-109

29. Wiktor V, Grosseau P, Guyonnet R, Garcia-Diaz E, Lors C (2011) Accelerated weathering of cementitious matrix for the development of an accelerated laboratory test of biodeterioration. Mater Struct 44(3):623-640
30. Johnson J (2008) Détérioration des silos-tours en béton. Ministère de l'Agriculture, de l'Alimentation et des Affaires Rurales Ontario, Fiche Technique 08-058

31. Bertron A (2004) Durabilité des matériaux cimentaires soumis aux acides organiques, Cas particulier des effluents d'élevage. PhD Thesis, INSA Toulouse

32. Barberousse H, Ruot B, Yéprémian C, Boulon G (2007) An assessment of façade coatings against colonisation by aerial algae and cyanobacteria. Build Environ 42(7):25552561

33. Escadeillas G, Bertron A, Blanc P, Dubosc A (2007) Accelerated testing of biological stain growth on external concrete walls. Part 1: development of the growth tests. Mater Struct 40(10):1061-1071

34. Escadeillas G, Bertron A, Ringot E, Blanc PJ, Dubosc A (2009) Accelerated testing of biological stain growth on external concrete walls. Part 2: quantification of growths. Mater Struct 42(7):937-945

35. Tran TH, Govin A, Guyonnet R, Grosseau P, Lors C, Garcia-Diaz E, Damidot D, Devès O, Ruot B (2012) Influence of the intrinsic characteristics of mortars on biofouling by Klebsormidium flaccidum. Int Biodeterior Biodegrad 70:31-39

36. Tran TH, Govin A, Guyonnet R, Grosseau P, Lors C, Damidot D, Deves O, Ruot B (2014) Influence of the intrinsic characteristics of mortars on their biofouling by pigmented organisms: Comparison between laboratory and field-scale experiments. Int Biodeterior Biodegrad 86:334-342

37. Giannantonio DJ, Kurth JC, Kurtis KE, Sobecky PA (2009) Effects of concrete properties and nutrients on fungal colonization and fouling. Int Biodeterior Biodegrad 63(3):252-259

38. Barberousse H, Tell G, Yéprémian C, Couté A (2006) Diversity of algae and cyanobacteria growing on building façades in France. Algol Stud 120(1):81-105

39. Gaylarde CC, Gaylarde PM (2005) A comparative study of the major microbial biomass of biofilms on exteriors of buildings in Europe and Latin America. Int Biodeterior Biodegrad 55(2):131-139

40. Rindi F (2007) Diversity, Distribution and ecology of green algae and cyanobacteria in urban habitats. In: Seckbach DJ (ed) Algae and cyanobacteria in extreme environments. Springer, Netherlands, pp 619-638

41. Giannantonio DJ, Kurth JC, Kurtis KE, Sobecky PA (2009) Molecular characterizations of microbial communities fouling painted and unpainted concrete structures. Int Biodeterior Biodegrad 63(1):30-40

42. Giovannacci D, Leclaire C, Horgnies M, Ellmer M, Mertz JD, Orial G, Chen J, Bousta F (2013) Algal colonization kinetics on roofing and façade tiles: influence of physical parameters. Constr Build Mater 48:670-676

43. Martinez T, Bertron A, Escadeillas G, Ringot E (2014) Algal growth inhibition on cement mortar: efficiency of water repellent and photocatalytic treatments under UV/ Vis illumination. Int. Biodeterior. Biodegrad. 89: 115-125

44. Maury-Ramirez A, De Muynck W, Stevens R, Demeestere K, De Belie N (2013) Titanium dioxide based strategies to prevent algal fouling on cementitious materials. Cem Concr Compos 36:93-100 
45. Graziani L, Quagliarini E, Osimani A, Aquilanti L, Clementi F, Yéprémian C, Lariccia V, Amoroso S, D’Orazio M(2013) Evaluation of inhibitory effect of $\mathrm{TiO}_{2}$ nanocoatings against microalgal growth on clay brick façades under weak UV exposure conditions. Build Environ 64:38-45

46. Urzì C, De Leo F (2007) Evaluation of the efficiency of water-repellent and biocide compounds against microbial colonization of mortars. Int Biodeterior Biodegrad 60(1):25-34

47. MacMullen J, Zhang Z, Dhakal HN, Radulovic J, Karabela A, Tozzi G, Hannant S, Alshehri MA, Buhé V, Herodotou C, Totomis M, Bennett N (2014) Silver nanoparticulate enhanced aqueous silane/siloxane exterior facade emulsions and their efficacy against algae and cyanobacteria biofouling. Int Biodeterior Biodegrad 93:54-62

48. Manso S, De Muynck W, Segura I, Aguado A, Steppe K, Boon N, De Belie N (2014) Bioreceptivity evaluation of cementitious materials designed to stimulate biological growth. Sci Total Environ 481:232-241

49. Verdier T, Coutand M, Bertron A, Roques C (2014) A review of indoor microbial growth across building materials and sampling and analysis methods. Build Environ 80:136-149

50. Gutarowska B, Piotrowska M (2007) Methods of mycological analysis in buildings. Build Environ 42(4):1843-1850

51. Mudarri D, Fisk WJ (2007) Public health and economic impact of dampness and mold. Indoor Air 17(3):226-235

52. Shirakawa MA, Tavares RG, Gaylarde CC, Taqueda MES, Loh K, John VM (2010) Climate as the most important factor determining anti-fungal biocide performance in paint films. Sci Total Environ 408(23):5878-5886

53. Shirakawa MA, Gaylarde CC, Sahão HD, Lima JRB (2013) Inhibition of Cladosporium growth on gypsum panels treated with nanosilver particles. Int Biodeterior Biodegrad 85:57-61

54. Gutarowska B, Pietrzak K, Machnowski W, Danielewicz D, Szynkowska M, Konca P, Surma-Slusarska B (2014) Application of silver nanoparticles for disinfection of materials to protect historical objects. Curr Nanosci 10(2):277-286

55. Verdier T, Coutand M, Bertron A, Roques C (2014) Antibacterial activity of $\mathrm{TiO}_{2}$ photocatalyst alone or in coatings on E. coli: influence of methodological aspects. Coatings (Submitted)

56. de Niederhãusern S, Bondi M, Bondioli F (2013) Selfcleaning and antibacteric ceramic tile surface. Int J Appl Ceram Technol 10(6):949-956

57. Valentin R, Alignan M, Giacinti G, Renaud FNR, Raymond B, Mouloungui Z (2012) Pure short-chain glycerol fatty acid esters and glycerylic cyclocarbonic fatty acid esters as surface active and antimicrobial coagels protecting surfaces by promoting superhydrophilicity. J Colloid Interface Sci 365(1):280-288

58. Gomes MI, Gonçalves TD, Faria P (2012) Earth-based repair mortars: experimental analysis with different binders and natural fibers. In: Mileto C, Vegas F, Cristini V (eds) Rammed earth conservation. CRC Press, Boca Raton

59. Khan BA, Warner P, Wang H (2014) Antibacterial properties of hemp and other natural Fibre plants: a review. BioResources 9(2):3642-3659
60. Pacheco-Torgal F, Jalali S (2012) Earth construction: lessons from the past for future eco-efficient construction. Constr Build Mater 29:512-519

61. Magniont C, Escadeillas G, Coutand M, Oms-Multon C (2012) Use of plant aggregates in building ecomaterials. Eur J Environ Civ Eng 16(sup1):s17-s33

62. Pacheco-Torgal F, Jalali S (2011) Cementitious building materials reinforced with vegetable fibres: a review. Constr Build Mater 25(2):575-581

63. Millogo Y, Morel J-C, Aubert J-E, Ghavami K (2014) Experimental analysis of pressed adobe blocks reinforced with Hibiscus cannabinus fibers. Constr Build Mater 52:71-78

64. Jonkers HM, Thijssen A, Muyzer G, Copuroglu O, Schlangen E (2010) Application of bacteria as self-healing agent for the development of sustainable concrete. Ecol Eng 36(2):230-235

65. Wiktor V, Jonkers HM (2011) Quantification of crackhealing in novel bacteria-based self-healing concrete. Cem Concr Compos 33(7):763-770

66. De Muynck W, Debrouwer D, De Belie N, Verstraete W (2008) Bacterial carbonate precipitation improves the durability of cementitious materials. Cem Concr Res 38(7):1005-1014

67. Van Tittelboom K, De Belie N, De Muynck W, Verstraete W (2010) Use of bacteria to repair cracks in concrete. Cem Concr Res 40(1):157-166

68. Belie ND (2010) Microorganisms versus stony materials: a love-hate relationship. Mater Struct 43(9):1191-1202

69. Decho AW (2010) Overview of biopolymer-induced mineralization: What goes on in biofilms? Ecol Eng 36(2):137-144

70. Soleimani S, Isgor OB, Ormeci B (2013) Resistance of biofilm-covered mortars to microbiologically influenced deterioration simulated by sulfuric acid exposure. Cem Concr Res 53:229-238

71. Soleimani S, Ormeci B, Isgor OB (2013) Growth and characterization of Escherichia coli DH5 $\alpha$ biofilm on concrete surfaces as a protective layer against microbiologically influenced concrete deterioration (MICD). Appl Microbiol Biotechnol 97(3):1093-1102

72. Ariño X, Ortega-Calvo J, Gomezbolea A, Saizjimenez C (1995) Lichen colonization of the roman pavement at Baelo-Claudia (cadiz, Spain)_biodeterioration vs bioprotection. Sci Total Environ 167:353-363

73. Ariño X, Gomez-Bolea A, Saiz-Jimenez C (1997) Lichens on ancient mortars. Int Biodeterior Biodegrad 40(2-4):217-224

74. Mori T, Nonaka T, Tazaki K, Koga M, Hikosaka Y, Noda $\mathrm{S}$ (1992) Interactions of nutrients, moisture and $\mathrm{pH}$ on microbial corrosion of concrete sewer pipes. Water Res 26(1):29-37

75. Herisson J, van Hullebusch E, Guegen-Minerbe M, Chaussadent T (2014) Biogenic corrosion mechanism: study of parameters explaining calcium aluminate cement durability. Presented at the International Conference on Calcium Aluminates, Avignon

76. Peyre Lavigne M, Bertron A, Auer L, Hernandez-Raquet G, Foussard J-N, Escadeillas G, Cockx A, Paul E (2014) An innovative approach to reproduce the biodeterioration 
of industrial cementitious products in a sewer environment. Part I: test design. Cem Concr Res (Submitted)

77. Herisson J, Guegen-Minerbe M, Chaussadent T, van Hullebusch E (2014) Development of a biogenic corrosion test to deliver durable structures in sewer networks. Presented at the International Conference on Calcium Aluminates, Avignon

78. Ehrich S, Helard L, Letourneux R, Willocq J, Bock E (1999) Biogenic and chemical sulfuric acid corrosion of mortars. J Mater Civ Eng 11(4):340-344

79. Vincke E, Verstichel S, Monteny J, Verstraete W (1999) A new test procedure for biogenic sulfuric acid corrosion of concrete. Biodegradation 10(6):421-428

80. Monteny J, Vincke E, Beeldens A, De Belie N, Taerwe L, Van Gemert D, Verstraete W (2000) Chemical, microbiological, and in situ test methods for biogenic sulfuric acid corrosion of concrete. Cem Concr Res 30(4):623-634

81. Yousefi A, Allahverdi A, Hejazi P (2014) Accelerated biodegradation of cured cement paste by Thiobacillus species under simulation condition. Int Biodeterior Biodegrad 86:317-326

82. Bensted J (1993) Effect of silage upon hardened cement and concrete. Cem Concr Res 1:3-10

83. Voegel C, Bertron A, Erable B (2014) Biological and chemical attack of cement-based materials in on-farm biogas plants. In: Proceedings of the international conference on durability of building materials and components, Sao Paulo

84. Bertron A, Duchesne J, Escadeillas G (2005) Accelerated tests of hardened cement pastes alteration by organic acids: analysis of the $\mathrm{pH}$ effect. Cem Concr Res 35(1):155-166

85. Bertron A, Duchesne J, Escadeillas G (2007) Degradation of cement pastes by organic acids. Mater Struct 40(3):341-354

86. Larreur-Cayol S, Bertron A, Escadeillas G (2011) Degradation of cement-based materials by various organic acids in agro-industrial waste-waters. Cem Concr Res 41(8):882-892

87. De Windt L, Bertron A, Larreur-Cayol S, Escadeillas G (2014) Interactions between hydrated cement paste and organic acids: Thermodynamic data and speciation modelling. Cem Concr Res, Submitted

88. Bertron A, Duchesne J, Escadeillas G (2005) Attack of cement pastes exposed to organic acids in manure. Cem Concr Compos 27(9-10):898-909

89. Bertron A, Larreur-Cayol S, Le TMT (2009) “Degradation of cementitious materials by some organic acids found in agroindutrial effluents", presented at the Final Conference of RILEM TC 211-PAE. Toulouse 1:96-107

90. Larreur-Cayol S, De Windt L, Bertron A, Escadeillas G (2011) Deterioration of cementitious materials by organic acids in agricultural effluents: experiments and modelling. In: Proceedings of the 7 th international symposium on cement based materials for a sustainable agriculture; CIGR international symposium, Quebec, pp 38-46

91. Voegel C, Bertron A, Erable B, Escadeillas G (2014) Chemical treatment with oxalic acid to improve the durability of cement-based materials in acid environments. In: Proceedings of the international conference on durability of building materials and components, Sao Paulo
92. Bertron A, Duchesne J, Escadeillas G (2007) Durability of various binders exposed to organic acids in liquid manure. In: Seventh Canmet/ACI international conference on durability of concrete, Montreal

93. Larreur-Cayol S, Bertron A, San Nicolas R, Escadeillas G (2011) Durability of different binders in synthetic agricultural effluents. In: Proceedings of the 7th international symposium on cement based materials for a sustainable agriculture; CIGR international symposium, Quebec, pp 56-66

94. Bertron A, Escadeillas G, de Parseval P, Duchesne J (2009) Processing of electron microprobe data from the analysis of altered cementitious materials. Cem Concr Res 39(10):929-935

95. Oueslati O, Duchesne J (2012) The effect of SCMs and curing time on resistance of mortars subjected to organic acids. Cem Concr Res 42(1):205-214

96. Pavlík V (1994) Corrosion of hardened cement paste by acetic and nitric acids part II: formation and chemical composition of the corrosion products layer. Cem Concr Res 24(8):1495-1508

97. Bertron A (2013) Methods for testing cementitious materials exposed to organic acids. In: Alexander M, Bertron A, Belie ND (eds) Performance of cement-based materials in aggressive aqueous environments. Springer, Dordrecht, pp 355-387

98. Gadd GM (1999) Fungal production of citric and oxalic acid: importance in metal speciation, physiology and biogeochemical processes. In: Poole RK (ed) Advances in microbial physiology, vol 41. Academic Press, London, pp 47-92

99. Grewal HS, Kalra KL (1995) Fungal production of citric acid. Biotechnol Adv 13(2):209-234

100. Monte M (2003) Oxalate film formation on marble specimens caused by fungus. J Cult Herit 4(3):255-258

101. de la Torre MA, Gomez-Alarcon G, Vizcaino C, Garcia MT (1992) Biochemical mechanisms of stone alteration carried out by filamentous fungi living in monuments. Biogeochemistry 19(3):129-147

102. Villar SEJ, Edwards HGM, Seaward MRD (2004) Lichen biodeterioration of ecclesiastical monuments in northern Spain. Spectrochim Acta A 60(5):1229-1237

103. Doherty B, Pamplona M, Miliani C, Matteini M, Sgamellotti A, Brunetti B (2007) Durability of the artificial calcium oxalate protective on two Florentine monuments. J Cult Herit 8(2):186-192

104. De Windt L, Devillers P (2010) Modeling the degradation of Portland cement pastes by biogenic organic acids. Cem Concr Res 40(8):1165-1174

105. Shi C, Stegemann J (2000) Acid corrosion resistance of different cementing materials. Cem Concr Res 30(5):803-808

106. Gruyaert E, Van den Heede P, Maes M, De Belie N (2012) Investigation of the influence of blast-furnace slag on the resistance of concrete against organic acid or sulphate attack by means of accelerated degradation tests. Cem Concr Res 42(1):173-185

107. Oueslati O, Duchesne J (2014) Resistance of blended cement pastes subjected to organic acids: quantification of anhydrous and hydrated phases. Cem Concr Compos 45:89-101 
108. Larreur-Cayol S (2012) Attaques des matériaux cimentaires par les acides organiques des effluents agricoles et agro-alimentaires. PhD Thesis, Université Paul Sabatier, Toulouse III

109. Bakharev T, Sanjayan JG, Cheng Y-B (2003) Resistance of alkali-activated slag concrete to acid attack. Cem Concr Res 33(10):1607-1611

110. Bernal SA, Rodríguez ED, de Mejía Gutiérrez R, Provis JL (2012) Performance of alkali-activated slag mortars exposed to acids. J Sustain Cem-Based Mater 1(3):138-151

111. Bernal SA, Provis JL (2014) Durability of alkali-activated materials: progress and perspectives. J Am Ceram Soc 97(4):997-1008

112. Sánchez E, Moragues A, Massana J, Guerrero A, Fernandez J (2009) Effect of pig slurry on two cement mortars: changes in strength, porosity and crystalline phases. Cem Concr Res 39(9):798-804

113. De Muynck W, Ramirez AM, De Belie N, Verstraete W (2009) Evaluation of strategies to prevent algal fouling on white architectural and cellular concrete. Int Biodeterior Biodegrad 63(6):679-689

114. Wiktor V, De Leo F, Urzì C, Guyonnet R, Grosseau P, Garcia-Diaz E (2009) Accelerated laboratory test to study fungal biodeterioration of cementitious matrix. Int Biodeterior Biodegrad 63(8):1061-1065

115. Peyre Lavigne M, Bertron A, Botanch C, Auer L, Hernandez-Raquet G, Cockx A, Foussard J-N, Escadeillas G, Paul E (2014) An innovative approach to reproduce the biodeterioration of industrial cementitious products in a sewer environment. Part II: validation on CAC and BFSC linings. Cem Concr Res (Submitted)

116. Peyre Lavigne M, Bertron A, Cockx A, Foussard J-N, Escadeillas G, Paul E (2014) New method for evaluation of cement-based material resistance against biogenic attack in sewer-like environment: comparison between CAC and CEM III coatings. Presented at the international conference on calcium aluminates, Avignon

117. Dossier A (2005) Argile, tome architecture et gestion du stockage géologique, Andra report C.RP.ADP.04.0001B

118. Walczak I, Libert M, Camaro S, Blanchard JM (2001) Quantitative and qualitative analysis of hydrosoluble organic matter in bitumen leachates. Agronomie 21(3):247-257

119. Devlin JF, Eedy R, Butler BJ (2000) The effects of electron donor and granular iron on nitrate transformation rates in sediments from a municipal water supply aquifer. J Contam Hydrol 46(1-2):81-97

120. Libert M, Bildstein O, Esnault L, Jullien M, Sellier R (2011) Molecular hydrogen: an abundant energy source for bacterial activity in nuclear waste repositories. Phys. Chem. Earth Parts ABC 36(17-18):1616-1623

121. Truche L, Berger G, Albrecht A, Domergue L (2013) Abiotic nitrate reduction induced by carbon steel and hydrogen: implications for environmental processes in waste repositories. Appl Geochem 28:155-163

122. Poulain S (2006) Caractérisation microbiologique de l'argile à Opalinus du Mont Terri et de l'argilite du Callovo-Oxfordien de Meuse/Haute-Marne. PhD Thesis, Université Sciences et Technologies-Bordeaux I

123. Poulain S, Sergeant C, Simonoff M, Le Marrec C, Altmann S (2008) Microbial investigations in opalinus clay, an argillaceous formation under evaluation as a potential host rock for a radioactive waste repository. Geomicrobiol $\mathbf{J}$ 25(5):240-249

124. Stroes-Gascoyne S, Schippers A, Schwyn B, Poulain S, Sergeant C, Simonoff M, Le Marrec C, Altmann S, Nagaoka T, Mauclaire L, McKenzie J, Daumas S, Vinsot A, Beaucaire C, Matray J-M (2007) Microbial community analysis of opalinus clay drill core samples from the Mont Terri Underground Research Laboratory, Switzerland. Geomicrobiol J 24(1):1-17

125. Stroes-Gascoyne S, Sergeant C, Schippers A, Hamon CJ, Nèble S, Vesvres M-H, Barsotti V, Poulain S, Le Marrec C (2011) Biogeochemical processes in a clay formation in situ experiment: part D-microbial analyses—synthesis of results. Appl Geochem 26(6):980-989

126. Williamson AJ, Morris K, Shaw S, Byrne JM, Boothman C, Lloyd JR (2013) Microbial reduction of Fe(III) under alkaline conditions relevant to geological disposal. Appl Environ Microbiol 79:3320-3326

127. Pedersen K, Nilsson E, Arlinger J, Hallbeck L, O’Neill A (2004) Distribution, diversity and activity of microorganisms in the hyper-alkaline spring waters of Maqarin in Jordan. Extremophiles 8(2):151-164

128. Whittleston RA, Stewart DI, Mortimer RJG, Burke IT (2009) Biostimulation of nitrate, iron and chromate reduction at hyperalkaline conditions. Geochim Cosmochim Acta 73:1436

129. Alquier M, Kassim C, Bertron A, Sablayrolles C, Albrecht A, Erable B (2014) Halomonas desiderata as a bacterial model to predict the possible biological nitrate reduction in concrete cells of nuclear waste disposals. J Environ Manag 132:32-41

130. Bertron A, Erable B, Alquier M, Jacquemet N, Kassim C, Sablayrolles C, Albasi C, Basseguy R, Strehaiano P, Vignoles M, Albrecht A, Escadeillas G (2013) Catalyse biotique et abiotique de la réduction des nitrates en milieu alcalin dans le contexte du stockage profond des déchets radioactifs. Matér Technol 101(1):104

131. Rafrafi Y, RanaivomananaH, Bertron A, Albrecht A, Erable B (2014) Abiotic and biotic reduction of nitrate at alkaline $\mathrm{pH}$ : conditions comparable to a nuclear waste repository. Int Biodeterior Biodegrad (Submitted)

132. Bertron A, Jacquemet N, Erable B, Sablayrolles C, Escadeillas G, Albrecht A (2014) Reactivity of nitrate and organic acids at the concrete-bitumen interface of a nuclear waste repository cell. Nucl Eng Des 268:51-57

133. Fomina M, Podgorsky VS, Olishevska SV, Kadoshnikov VM, Pisanska IR, Hillier S, Gadd GM (2007) Fungal deterioration of barrier concrete used in nuclear waste disposal. Geomicrobiol J 24(7-8):643-653

134. Wolf M, Bachofen R (1991) Microbial legradation of bitumen. Experientia 47(6):542-548

135. Roffey R, Norqvist A (1991) Biodegradation of bitumen used for nuclear waste disposal. Experientia 47(6):539-542

136. Perfettini JV, Revertegat E, Langomazino N (1991) Evaluation of cement degradation induced by the metabolic products of two fungal strains. Experientia 47(6):527-533

137. Pedersen K (2001) Microbial features, events and processes in the Swedish final repository for lowand intermediate-level radioactive waste (Project SAFE), Göteborg University, Stockholm, SKB Report R-01-05 
138. Newsome L, Morris K, Lloyd JR (2014) The biogeochemistry and bioremediation of uranium and other priority radionuclides. Chem Geol 363:164-184

139. Simonoff M, Sergeant C, Poulain S, Pravikoff MS (2007) Microorganisms and migration of radionuclides in environment. Comptes Rendus Chim 10(10-11):1092-1107

140. Kagawa A, Fukumoto M, Kawamura K (2000) Influence of chemical and radiolytic degradation of bitumen on its performance for disposal. J Nucl Sci Technol 37(10):934-937

141. Libert M, Walczak I (2000) Effect of radio-oxidative ageing and $\mathrm{pH}$ on the release of soluble organic matter from bitumen, Avignon, $\mathrm{p} 4$

142. Van Loon LR, Kopajtic Z (1990) Complexation of $\mathrm{Cu}^{2+}$, $\mathrm{Ni}^{2+}$ and $\mathrm{UO}^{22+}$ by radiolytic degradation products of bitumen," Nagra, Technical Report NTB 90-18

143. Walczak I (2000) Determination des produits organiques d'altérations chimiques et radiochimiques du bitume: applications aux enrobes bitumes, $\mathrm{PhD}$ Thesis, INSA Lyon

144. Larreur-Cayol S, De Windt L, Bertron A, Escadeillas G (2011) Deterioration of cementitious materials by organic acids in agricultural effluents: experiments and modelling. Presented at the 7 th international symposium on cement based materials for a sustainable agriculture; CIGR international symposium, pp 38-46

145. Glaus MA, van Loon LR, Achatz S, Chodura A, Fischer K (1999) Degradation of cellulosic materials under the alkaline conditions of a cementitious repository for low and intermediate level radioactive waste: part I: identification of degradation products. Anal Chim Acta 398(1):111-122

146. Knill CJ, Kennedy JF (2003) Degradation of cellulose under alkaline conditions. Carbohydr Polym 51(3): 281-300

147. Bertron A, Ranaivomanana H, Jacquemet N, Erable B, Sablayrolles C, Escadeillas G, Albrecht A (2013) Physicochemical interactions at the concrete-bitumen interface of nuclear waste repositories. EPJ Web Conf 56:01002

148. Truche L (2013) Effet catalyt; que des aciers et produits de corros;on sur la réduction abiotique des nitrates par $\mathrm{H}_{2}$ en condition de stockage MAVL-impact des fortes concentrations en nitrate et de la disponibilité des sites réactifs sur les aciers, Université de Lorraine, Géoressources, Andra report CCRPFSTRI 30039

149. Truche L, Berger G, Albrecht A, Domergue L (2013) Engineered materials as potential geocatalysts in deep geological nuclear waste repositories: a case study of the stainless steel catalytic effect on nitrate reduction by hydrogen. Appl Geochem 35:279-288

150. Tiedje NM (1981) Use of nitrogen-13 and nitrogen-15 in studies on the dissimilatory fate of nitrate, In: Lyons JM et al (eds) Genetic engineering of symbiotic nitrogen fixation and conversation of fixed nitrogen. Plenum Press, New York, pp 481-497

151. Erable B, Bertron A, Rafrafi Y, Kassim C, Albrecht A (2014) Evaluation of microbial denitrifying kinetics by Halomonas desiderata in a continuous bioreactor simulating the alkaline conditions inside cement-based cell for nuclear waste disposal. Biotechnol Bioeng (In preparation)

152. Libert M, Pointeau I, Sellier R, Lillo M, Burke IT, Stewart DI, Whittleston RA, Albrecht A (2011) Nitrate reducing bacterial activity under alkaline conditions found in intermediate-level nuclear waste repositories. Presented at the 1 st international symposium on cement-based materials for nuclear wastes NUWCEM, Avignon

153. Rafrafi Y, Ranaivomanana H, Erable B, Bertron A, Kassim C, Sablayrolles C, Albasi C, Basseguy R, Escadeillas G, Vignoles M (2013) Bio-réactivité des nitrates en milieu cimentaire en présence de matière organique et/ou d'H2Exploitation du dispositif pilote et prise en compte de la corrosion, LMDC-LGC-LCA, Toulouse, Andra report CGRPFSTR140005,

154. Rizoulis A, Steele HM, Morris K, Lloyd JR (2012) The potential impact of anaerobic microbial metabolism during the geological disposal of intermediate-level waste. Miner Mag 76(8):3261-3270

155. Berendes F, Gottschalk G, Heine-Dobbernack E, Moore ERB, Tindall BJ (1996) Halomonas desiderata sp. nov, a new alkaliphilic, halotolerant and denitrifying bacterium isolated from a municipal sewage works. Syst Appl Microbiol 19(2):158-167

156. Arter HE, Hanselmann KW, Bachofen R (1991) Modelling of microbial degradation processes: the behaviour ofmicroorganisms in a waste repository. Experientia 47(6):578-583

157. McKinley IG, Grogan HA (1991) Consideration of microbiology in modelling the near field of a L/ILW repository. Experientia 47(6):573-577

158. André L, Pauwels H, Dictor M-C, Parmentier M, Azaroual M (2011) Experiments and numerical modelling of microbially-catalysed denitrification reactions. Chem Geol 287(3-4):171-181 